Mirostaw Mróz*

Toruń

\title{
Bliskość i nieskończoność. Kilka uwag na temat obecności Boga w świecie na kanwie „filozofii negatywnej" św. Tomasza z Akwinu odczytanej dzisiaj
}

\section{Bóg ,daleki” - ,bliski” a stosowność poszukiwań w obrębie myśli św. Tomasza}

Współczesny człowiek znajduje się w stanie sprzeczności: z jednej strony pragnie bliskości Boga, nie chce Boga transcendentnego, oddalonego, z drugiej jednak pragnie działać sam, w pełnej autonomii, nie lubi bowiem, gdy mu się ktoś wtrąca do życia, nawet Bóg. Boga najczęściej odczuwa jako dalekiego. Także współczesna filozofia religii mówi o Bogu najczęściej jako o kimś nieznanym, o Bogu, który jest milczeniem ${ }^{1}$ Obawa, która się przejawia w mówieniu o Bogu, wynika z faktu pewnego niebezpieczeństwa, ukazanego w Biblii, w wydarzeniu Aarona i złotego cielca (por. Wj 32). Izraelici, bojąc się, że ich Mojżesz, wraz z samym Bogiem, opuścił, proszą Aarona o stworzenie wizerunku Boga, który wyprowadził ich z Egiptu. Aaron charakteryzował się wielką „wymownością”, w przeciwieństwie do jąkającego się Mojżesza. To za sprawą „złotoustego” Aarona zjawia się obszar porażki w prezentowaniu najwyższego Boga w formie bożka. Dylemat od zawsze aktualny: w jaki sposób prezentować Boga, jak o Nim mówić? W jaki spo-

* Ks. prof. dr hab. Mirosław Mróz jest profesorem nauk teologicznych w zakresie teologii moralnej oraz doktorem filozofii, kieruje Zakładem Teologii Moralnej i Katolickiej Nauki Społecznej na Wydziale Teologicznym Uniwersytetu Mikołaja Kopernika w Toruniu.

${ }^{1}$ Por. M. Szulakiewicz, Religia i czas, WN UMK, Torun 2008, s. 31. 
sób rozpoznać obecność Boga? Człowiek bowiem pragnie zawsze, aby Bóg był z nim. Gorzej, gdy zapragnie on, aby Bóg chodził „za” nim, „za” jego pomysłami, „za" jego regułami i wyobrażeniem. Jednak człowiek może też to sprawić, że Bóg staje się „bezdomny”, „nie może już nigdzie być”, „przestrzeń istnienia nie przynosi już nieskończoności”’. Czy kłamstwo złotego cielca ujawnia się jako zawsze aktualne? Już nie ma miejsca dla niego w ,przestrzeni” świata? Mnisi jednak wiedzą że gdy zapadnie milczenie, nie znaczy to, że mowa się kończy. Mamy do czynienia z inną jej postacią. Gdy spojrzy się w innym kierunku poza świat widzialny, a więc „w głąb” siebie, czy już rzeczywiście nic nie widzimy? A może należy wpatrzyć się w rzeczy dokładniej? Nie zatrzymać się jedynie przy ich faktyczności i odgadnąć ich rzeczywistość, to, czym są. Boga ukrywającego się „za” nimi. Czy Bóg jednak ukrywa się za światem?

Potrzebę bliskości Boga widać także w słowach Mojżesza. W Księdze Powtórzonego Prawa możemy przeczytać zdumiewające zdanie, ukazujące specyfikę obecności Boga w historii Izraela: „Z pewnością ten wielki naród to lud mądry i rozumny. Bo któryż wielki naród ma bogów tak bliskich, jak Pan, Bóg nasz, ilekroć Go wzywamy?” (Pwt 4, 7). Tu Bóg jest tym, z którym możliwa jest nawet wzajemna więź, określana, jak sformułuje to M. Buber, jako zasada relacji ,Ja"-Ty”.

Gdy zwrócimy się w tym momencie do Tomasza z Akwinu, w pierwszym odruchu wydaje się nam, że dla rozwiązania tego dylematu jest on autorem raczej nietrafionym. $Z$ reguły przedstawia się go jako teologa pozytywnego, który na wszystko ma odpowiedź, i to taką, która współczesnemu człowiekowi wydaje się mało co mówić.

Czy łącząc bliskość Boga i Jego oddalenie, nieskończoność ze skończonością, możemy odkryć w myśli Akwianty coś ciekawego? Wydaje się bowiem, że zagadnienie poznawalności i bliskości Boga jest raczej problematyką właściwą nowoczesności, gdzie rozumnie się ową „bliskość” jako relację, jako wzajemne zbliżenie. Jest jednak także drugie oblicze współczesnej filozofii religii, gdzie dominuje tendencja prezentacji Boga jako nieznanego, jako niewypowiedzianego, który choć jest blisko, pozostaje dla człowieka ciagle tajemnica. Z jednej strony „oddalenie” i „zakrycie”, z drugiej Jego „ukazanie się" i „objawienie”. Wydaje się, że te tematy nie dotyczą Akwinaty. Przedstawiany jest on najczęściej jako ten, który Boga przesłonił pojęciem bytu. Kto zaś - jak powie w jednej ze swoich ostatnich książek Religia i czas toruński filozof religii Marek Szulakiewicz - ,zaczyna

2 Por. T. Halik, Noc spowiednika. Paradoksy małej wiary w epoce postoptymistycznej, thum. A. Babuchowski, Księgarnia św. Jacka, Katowice 2005, s. 44.

${ }^{3}$ Por. M. Buber, Ja i Ty, thum. J. Doktór, Pax, Warszawa 1992. 
od bytu [...], ten najczęściej, zaczyna od bożka, którego sobie wytworzył"4. Tutaj moge jedynie M. Szulakiewiczowi przyklasnąć i stanąć w szeregu razem z nim, ostatecznie chodzi bowiem o Boga żywego. Można bowiem nasz wzrok skierować nie na to, co się znajduje za szybą, ale na samą szybę. I rzecz jasna, że wtedy jeszcze nie docieramy do Boga jako Osoby, a tylko do twierdzeń, mogących być miejscem budowania światopoglądu i ideologii. M. Heidegger w swojej książce Bycie $i$ czas odnotowuje: „Tylko w rzeczywistym mówieniu jest właściwe milczenie"5. Rzeczywiste mówienie o Bogu, a zarazem właściwe milczenie, właściwe jest filozofii Boga prezentowanej przez Akwinatę, chociaż zdaję sobie sprawę, że wielu z takim zdaniem może się nie zgadzać. Najczęściej wynika to z faktu, że pewnie i sam Tomasz nie przyznałby się dzisiaj do tomizmu. Akwinta nie jest zapewne tym, który od bytu zaczyna, chociaż zapewne tym pojęciem się posługuje.

Zapewne Akwinata jest z krwi i kości metafizykiem, ale jednak metafizykiem specyficznym: nie jest bowiem metafizykiem „statycznym”, „esencjalistycznym”, a jest, w pełni tego wymiaru, metafizykiem kontemplacyjnym. Często widzi się Tomasza jedynie w okularach ideologicznych wypaczeń, gdy tymczasem, jak to dobitnie wykazuje S. Swieżawski, filozofem profetycznym, nielękającym się tajemnicy. Natomiast Gilles Emery OP w swoim studium na temat Pars Prima Sumy teologii wskaże, że już zaraz pierwszy Tomaszowy traktat o Bogu nie może być widziany jako rywalizacja między istotą i relacją, i wysunięciem na pierwszy plan nauki o bycie, omijając jego odniesienia do tajemnicy Boga i relacji osobowych ${ }^{6}$. Tę myśl pragniemy w naszych analizach podjąć i uwypuklić. A mianowicie, że Tomasz w swojej prezentacji bycia nieskończonego Boga w świecie stosuje ową komplementarność „bliskości” i „oddalenia”, zachowanej tajemnicy i naoczności. Akwinata, operując bowiem tradycyjnym pojęciem bytu, nie zapomina o tym, że człowiek nigdy nie zdoła na tyle zbliżyć się do Boga, aby Go ująć i posiąść dla siebie. Nasza analiza pragnie być tutaj próbą wykazania u Tomasza obecności owego styku nieskończoności ze skończonościa, owych komplementarnych odniesień: bytu i relacji, przestrzeni i czasu, chociaż są one często raczej przeczute niż wyraźnie wyartykułowane, tak jakby tego chciała współczesna fenomenologia.

Mówi się dzisiaj wiele o końcu, a przynajmniej kryzysie teologii metafizycznej. Wstrząs spowodowany przez Heideggera (ogłoszenie ,zapomnienia

${ }^{4}$ M. Szulakiewicz, dz. cyt., s. 40.

${ }^{5}$ M. Heidegger, Bycie i czas, thum. B. Baran, PWN, Warszawa 1994, s. 44.

${ }^{6}$ Por. G. Emery, Esencjalizm czy personalizm w Tomaszowym traktacie o Bogu, w: Święty Tomasz teolog. Wybór studiów, Instytut Tomistyczny-Wydawnictwo Antyk, Warszawa-Kęty 2005, s. 315-351. 
o bycie” oraz jego odkrycie „bycia i czasu”) ostatecznie okazał się korzystny dla tomizmu. Heidegger jest dzisiaj dla tomistów potężnym bodźcem, który zmusza do wydobywania na jaw w myśli Akwinaty nie tylko utartych szlaków, ale nowych rozróżnień i odczytań. W tym kontekście przychodzą mi na myśl słowa Étienne'a Gilsona z jego książki Byt $i$ istota: „Prawdziwej metafizyce bytu brak było zawsze «fenomenologii», do której miała prawo, zaś «fenomenologia» współczesna nie posiada metafizyki, która jedynie może ją uzdrowić, a uzasadniając ją - wskazywać jej drogę"7. Bliskość Boga w świecie stworzonym to temat zapewne obecny u Akwinaty, zaraz w pierwszych kwestiach jego Sumy teologii, a który wpisuje się w klasyczne treści jego filozofii. Czy jednak i na ile odpowiada on na autentyczne dylematy człowieka współczesnego w pytaniach o obecność Boga, nie tyle jednak zależy od szykowności jego argumentów, ile od jego zdolności podprowadzania innych „do źródła”, gdzie można usłyszeć głos Niewypowiedzianego i cieszyć się byciem razem z Nim.

\section{Obecność dyskursu „teologii negatywnej” u św. Tomasza}

W filozofii św. Tomasza oprócz mówienia wyraźnie pozytywnego i metafizycznego istnieje pewna kluczowa, w pewnym sensie ukryta idea, która determinuje jednak jego prawdziwe spojrzenie na Boga. W interpretacji tekstu św. Tomasza, którym chcę się tu posłużyć, a mianowicie kwestią ósmą z Pars Prima jego Summa Theologiae: De existentia Dei in rebus, „właściwie to, co powiedziane, zawarte jest w tym, co nie jest powiedziane". Kwestię 8 trzeba odczytywać jako kontynuację kwestii 7, obie są pewną całością, gdzie 7 napisana jest w kluczu „teologii negatywnej”. Można powiedzieć, że przez słowa Akwinaty zawarte w kwestii 8 Pars Prima Sumy teologii ujawnia sięjakby przez szczelinę w budowli - swoistego rodzaju logika i tok myślowy, który tym samym przypomina dyskurs współczesnej filozofii religii.

Kwestia 8 O byciu Boga w rzeczach pojawia się niespodziewanie. Można byłoby oczekiwać, że Tomasz dalej będzie toczył swoje rozważania na temat kolejnych przymiotów Boga. A raptem po omówieniu nieskończoności Boga (kwestia 7: De infinitate Dei) pojawia się przedziwne zapytanie. W jaki sposób Bóg, który jest nieskończony, może być we wszystkich rzeczach? Utrum Deus sit in omnibus rebus. Jak to możliwe, że nieskończoność i skończoność mogą się spotkać? A co za tym idzie także odkrycie sprawy bliskości i obecności Boga: „bytujący” tu, teraz, przy mnie, a może też i we mnie? Czy nie są to pytania egzystencjalne? Oczywiście, Tomasz nie stawia kwestii egzy-

\footnotetext{
${ }^{7}$ É. Gilson, Byt i istota, thum. P. Lubicz, J. Nowak, Pax, Warszawa 1963, s. 18.
} 
stencjalnie we współczesnym tego słowa znaczeniu. Pojęcie nieskończoności i samo zrozumienie nieskończoności Boga umieszcza najpierw w całkowitym oddzieleniu, w pełnym wyprowadzeniu Go poza materię (kwestia 7), potem w kwestii 8 najbliżej jak tylko można. Tym samym Tomasz zapyta się: Czy Bóg może być znany bezpośrednio, skoro tylko to, co skończone, jest poznawalne w ten sposób? Boga znamy jedynie jako nieznanego, raczej przez negację niż przez afirmację. Tomasz w Pars Prima, w kwestii 7, zdecydowanie podkreśla oddzielenie Boga od innych bytów. Nieskończoność jest najtrudniejsza do uchwycenia dla ludzkiego umysłu, dlatego że tym, co człowieka otacza, jest permanentne obcowanie ze skończonością.

Tomasz w kwestii 7 podejmuje dyskurs i myślenie Jana Damasceńskiego. Ten święty to ostatni z Ojców Kościoła na Wschodzie (+ ok. 749), który kontynuuje dzieło Pseudo-Dionizego Areopagity. Bóg wznosi się ponad wszelki byt i poznanie i dlatego droga poznania Boga odbywa się sposobem myślenia apofatycznego, czyli drogą negacji. Nie poznajemy natury Boga, poznajemy jedynie jej przejawy: niematerialność, niezmienność, nieograniczoność, nieskończoność. Tomasz zna jeszcze jedną formę orzekania o nieskończoności Boga: przez prywację. Tę jednak prezentuje w Summa contra gentiles $^{8}$, czy w Compendium theologiae ${ }^{9}$. Tutaj powstrzymuje się od tej interpretacji i idzie ku teologii negatywnej.

W swoim Komentarzu do $O$ imionach Bożych Pseudo-Dionizego Areopagity sam Tomasz tak pisze o tej metodzie orzekania o Bogu. Jest to jedna z bardziej dobitnych jego wypowiedzi wskazujących, że Bóg jest ponad wszelkim rodzajem i gatunkiem ${ }^{10}$.

[Bóg jest] ponad wszelką wypowiedzią i nad wszystkim naszym poznaniem i nie tylko przekracza nasze mówienie i poznanie, lecz całkowicie trwa ponad wszelkim umysłem, także anielskim, oraz ponad wszelką substancją [...]. Jest On dla wszystkich rzeczy nieogarniany i ani nie może być ujęty zmysłami, ani w fantazji czy wyobraźni, ani w mniemaniach, przy pomocy których porozumiewają się zwierzęta; nie może być także pojęty przez to, co jest właściwe istotom rozumnym: ponieważ ani nie ma On imienia, aby je można było ujać, ani żadna złożona wypowiedź nie odnosi się do Niego, ani wyczucie, czyli prosta intuicja umysłu, ani wiedza, która pochodzi z wyciagania z przesłanek wniosków ${ }^{11}$.

${ }^{8}$ Por. Summa contra gentiles, I, 43.

9 Por. Compendium theologiae, 18.

${ }^{10}$ Por. S. Th., I, q. 3, a. 5: Deus est principium totius esse [...]. Unde non continetur in aliquo genere sicut principium.

${ }^{11}$ De div. nom., c. 1, 1. 3, nr 77. 
Ten sposób niemożliwości ujmowania Boga w jakikolwiek sposób zdaje się potwierdzać także Katechizm Kościoła katolickiego, gdy stwierdza: „Bóg przewyższa wszelkie stworzenie” ( $\mathrm{nr} 42)$. Uzmysłowienie sobie natury nieskończoności Boga zdaje się wykluczać możliwość Jego poznania, a w konsekwencji adekwatnego mówienia o Nim. Katechizm powie także: „Słowa ludzkie pozostają zawsze nieadekwatne wobec tajemnicy Boga" (nr 42). Wróćmy jednak do Tomasza. To on właśnie, jak zauważa to Józef Pieper w swojej analizie o elemencie negatywnym w filozofii św. Tomasz z Akwinu ${ }^{12}$, traktat o Bogu rozpoczyna zdaniem: „Nie jesteśmy zdolni poznać, czym Bóg jest - możemy tylko wiedzieć, czym On nie jest”. W Komentarzu do Boecjusza znajduje się zaś miejsce dla jego poglądu, że ,istnieją trzy stopnie ludzkiej wiedzy o Bogu: pierwszym jest poznać Boga działającego w stworzeniach - drugim - poznać Go w zwierciadle bytów duchowych, a trzecim, najwyższym - znać Go jako nieznanego - Deum tamquam ignotus”13. Podobnie w samym De veritate: „Oto najwyższy stopień ludzkiej wiedzy o Bogu: wiedzieć, że Boga nie znamy” (ut sciat se Deum nescire ${ }^{14}$. Czyż można się jednak dziwić takim stwierdzeniom Akwinaty? Kiedy bowiem wczytamy się np. w kwestię 7, w Pars Prima, „O nieskończoności Boga”, sytuacja wyda się całkiem oczywista. „Boga nikt nigdy nie widział" $(\mathrm{J} 1,18)$, gdyż jako nieskończony jest On przecież oddzielony, wyprowadzony poza materię. Tomasz, gdy omawia nieskończoność Boga, rozpoczyna od wytknięcia starożytnym błędnego ujęcia Jego natury, przypisującego Mu nieskończoność materialną (infinitas materialis). Bóg jest niezmierzony w swojej nieskończoności przez istotową nieobecność granic. Nie jest to więc prosty brak granic, ale nieskończoność Boga wynika z samej istoty Jego Bytu, całkowicie przewyższającego nasze wyobrażenie o Nim samym, wynikające niejako z naszej beznadziejności uzmysłowienia sobie Jego natury. Dla Tomasza nieskończoność to jeszcze coś innego niż istotowa nieobecność granic, a wiążąca się z łacińskim terminem słowa in-finitas. Pojęcie infinitas zawiera w sobie to, co całkowicie doskonałe, pełne, a przede wszystkim to, co posiada w sobie samym swój własny cel. Idąc za Arystotelesem, Akwinata będzie widział zgodnie z etymologią słowa finis cel, że to, co skończone, ma przyczynę celową poza sobą samym, w Bogu, który jest infinitas, a tym samym, to On sam jest celem dla wszystkich rzeczy stworzonych. Tomasz przerzuci więc ciężkość „granic”, a raczej ich nieobecności w Bogu, poza obszar nieokreśloności i materii, a skoncentruje się

12 J. Pieper, Prawda i niepoznawalność. Element negatywny w filozofii św. Tomasza z Akwinu, „Znak” 89 (1961), s. 1500-1514.

${ }^{13}$ In Boethium de Trin., I, 2, ad 1.

${ }_{14}$ De veritate, VII, 5, ad 14. 
na nieskończoności istoty Boga, doskonałości i celu. Bóg, będąc czystą formą, i znajdując się w pełnym urzeczywistnieniu, jest właśnie nieskończony, actus purus. Dlatego Tomasz będzie dowodził, że nic poza Bogiem nie może być nieskończone przez swą istotę: „Poza Bogiem żadna rzecz nie może być nieskończona: zasadniczo - istotnie; może taką być tylko pod jakimś względem (aliquid praeter Deum potest esse infinitum secundum quid, sed non simpliciter) ${ }^{\prime 15}$. „,Rzecz [natomiast], zasadniczo, tj. w swojej istocie [jest] już skończona, już ograniczona pod jakimś względem: może [bowiem jednak] w nieskończoność podlegać dalszym kształtowaniom" ${ }^{16}$. W ten sposób św. Tomasz zdecydowanie odróżnia byt Boga od innych bytów, ponieważ nie przysługuje nieskończoność simpliciter (zasadniczo). Także aniołowie są bytami nieskończonymi tylko „pod pewnym względem” (secundum quid), chociaż nie są ograniczeni, tak jak na przykład człowiek przez materię. Odróżnia je jednak od Boga to, że są oni skończeni ze względu na występujące w nich złożenie z istoty (formy) i istnienia. Akwinata sam zapyta: „Przez co Bóg jest nieskończony, odrębny od wszystkich innych stworzeń (distinguitur ab omnibus aliis), a wszystko inne staje się odrębne i dalekie od Niego (alia removetur ab eo)" "17? Odpowiedź może być tu tylko jedna: przez to właśnie, że Bóg jest samoistnym istnieniem: ipsum esse subsistens ${ }^{18}$.

Widzimy tutaj dobitnie Tomaszowy element filozofii negatywnej, gdzie mówienie o nieskończoności Boga musi z konieczności odbywać się w formie teologii apofatycznej. Tutaj teologia potrzebuje filozofii, tym bardziej że pojęcie nieskończoności nie pojawia się wprost w Biblii, która jest podstawowym źródłem dyskursu teologicznego. Wcześni teologowie, Ojcowie Kościoła, patrzyli na pojęcie nieskończoności z dużą rezerwą, co udziela się w pewnym sensie także Akwinacie, bo gdy zapyta: „Czy Bóg jest nieskończony?”, widać świadomość potrzeby pogłębienia znaczenia tego przymiotu Bożego. I to zarówno w stosunku do stanowisk błędnych interpretacji filozoficznych, jak i samego Arystotelesa. Dla Tomasza ostatecznym uzasadnieniem nieskończoności Boga jest fakt, że jest On samym istnieniem. Jego odpowiedź zaś: ,istnienie Boga nie jest istnieniem przyjętym w czymś, gdyż Bóg - to jest istnienie, istnienie samoistne"19, oddziela (separuje) zdecydowanie Boga od stworzeń, bytów skończonych. Wyraźnie to widać w teksie Summa contra gentiles, gdzie pisze: „Każda rzeczywistość w czymś tkwiąca jest ograniczona przez to, w czym istnieje, to bowiem, co jest w czymś drugim, istnieje na sposób podmiotu przyjmujące-

\footnotetext{
15 S. Th., I, q. 7, a. 2c.

16 Tamże.

${ }^{17}$ S. Th., I, q. 7, a. 1, ad 3.

18 Por. np. S. Th., I, q. 4, a. 2c.

19 S. Th., I, q. 7, a. 1c.
} 
go. Rzeczywistość więc nieistniejąca w niczym nie jest niczym nieograniczona [...]. Bóg zaś jest rzeczywistością nieistniejącą w żaden sposób w czymś drugim [...] jest On bowiem sam swoim istnieniem [...]. Pozostaje więc, że jest On nieskończony" ${ }^{20}$. Wraz z nieskończonością Boga wkracza więc na arenę Jego oddzielenie, odrębność względem stworzeń (bytów skończonych), jak i dystans (Bóg będący daleko): alia removetur $a b e o^{21}$.

Pojęcie nieskończoności Boga zadomowiło się na dobre u Tomasza, zawsze jednak z tym pewnym pogłębionym spojrzeniem, które ma na względzie wskazanie na Jego jedyność. Jest tylko jeden Bóg, i nie ma w Nim żadnego złożenia ani części, ani przypadłości ${ }^{22}$. Nieskończoność jako przymiot Boga oznacza więc w jego ujęciu absolutyzację, co zbliża się do koncepcji Absolutu w ujęciu filozoficznym. Trzeba jednak też tutaj pamiętać, że Akwinata jest jednak zawsze świadomy tej prawdy chrześcijańskiej, iż w Chrystusie nieskończony Bóg, przekraczając granice skończoności, od strony nieskończoności zagościł w niej. Podobnie człowiek usiłuje przekroczyć granice skończoności w kierunku nieskończoności, tak swoim intelektem, jak i pożądaniem (wolą). Te fakty natury teologicznej: wstępowanie Boga w sferę tego, co skończone (Wcielenie), i człowieka (przez łaskę), w sferę nieskończoności i bezczasowości Boga, będą rzutowały na końcowe, ostateczne spojrzenie św. Tomasza na przymiot nieskończoności Boga, sam wydobyty nie tyle z Biblii, co z filozofii.

To jest właśnie ów punkt, który na podstawie tekstów Akwinaty (szczególnie Pars Prima, a. 8) szczególnie nas tu interesuje: relacja (bliskość) Nieskończonego do tego, co skończone. A także, jako konsekwencja, zastanowienie nad pytaniem: Jak to, co skończone, może nadać pozytywne znaczenie samej nieskończoności (i wzajemnie)?

Wychodząc z tych założeń, a wracając na pole tradycji apofatycznej (filozofii i teologii negatywnej), trzeba powiedzieć, że rzeczywiście spojrzenie na nieskończonego Boga musi pozostać dla naszych zmysłów i rozumu tu na tej ziemi nieuchwytne. Nie jesteśmy w stanie ogarnąć ani odkryć, kim naprawdę jest Bóg. Ojcowie Kościoła, wyczuwając ludzką bezsilność wobec niezmierzoności i niepojętności Boga, zawsze nawoływali, że trzeba Jego tajemnice uczcić poprzez milczenie. Tu było miejsce na wprowadzenie ikony, która wchodzi w przestrzeń tego milczenia i modlitwy ludzi ortodoksyjnego Wschodu ${ }^{23}$. Ikona i milczenie są tu miejscami przebicia skoń-

${ }^{20}$ Summa contra gentiles, I, 43.

${ }^{21}$ S. Th., I, q. 7, a. 1, ad 3.

22 Summa contra gentiles, I, 43.

${ }^{23}$ P. Evdokimov, Teologia della bellezza. L'arte dell'icona, Edizioni Paolone, Roma 1984, s. 131-134. 
czoności ku nieskończoności, stąd tylko czyste serce może malować ikonę, ślady nieskończoności Boga w skończonym świecie. Myśl pozytywna, która uzasadnia istnienie Boga drogą analogicznej struktury bytu i analogicznego orzekania, napotyka tutaj pytanie: Czy wolno człowiekowi w ogóle pytać o Boga, o Jego istnienie? Skoro jest on oddzielony, niewyrażalny, całkowicie Inny? Tomasz, który stosuje do myśli chrześcijańskiej poglądy Arystotelesa, w świetle tego, co do tej pory zostało powiedziane, zachowuje tu jednak (drogą Pseudo-Dionizego Areopagity) czytelne ślady myśli platońskiej, dokładniej neoplatońskiej. Otwiera się zatem zupełnie inna przestrzeń hermeneutyczna, jakby bliższa myśli współczesnej, przynajmniej filozoficznemu sposobowi prezentowania kwestii teologicznych (teologii naturalnej). Atrybut nieskończoności Boga wprowadził nas w przestrzeń tych właśnie odniesień, gdzie pytaniem staje się problem relacji pomiędzy Bytem, który jest, a tymi bytami, którym udziela On istnienia. Pytanie dotyczy metafizycznej obecności i metafizycznej relacji Boga ze światem, z rzeczami. Relacji pomiędzy bytem koniecznym a bytem istniejącym dzięki udzielonemu istnieniu. Łacińska sentencja: conservatio est continua creatio (zachowanie bytu $\mathrm{w}$ istnieniu jest jego nieustannym stwarzaniem) zdaje się wyznaczać pierwszy sposób drogi rozwiązań na postawione pytania. Niemniej potrzebują one jeszcze bardziej pogłębionej argumentacji. Tutaj zaś możemy być spokojni, gdyż trzeźwy umysł Akwinaty nie pozostawia nas bez odpowiedzi.

\section{Między nieskończonością Boga a skończonością rzeczy: pola obecności}

Święty Tomasz swoje dociekania o bliskości Boga, o czym już tutaj zostało wspomniane, porusza w Summa Theologiae, Pars Prima, kwestia 8, w czterech artykułach. Pyta tutaj: „Czy Bóg jest we wszystkich rzeczach?”, „Czy Bóg jest wszędzie?”, „Czy Bóg jest wszędzie swoją istota, potęga i obecnością?”, „Czy wszechobecność jest przymiotem znamionującym wyłączność Boga?” Takie pytania postawione zaraz po tym, jak stwierdzona została nieskończoność Boga, jego oddzielenie i oddalenie od świata, człowieka, wszystkich bytów skończonych (kwestia 7), wydają się wręcz prowokacyjne, sprzeczne ze zdrowym rozsądkiem albo wręcz bluźniercze. Przecież stwierdzono radykalne niepodobieństwo bytów skończonych i Bytu nieskończonego, wręcz niemożliwość Jego poznania i mowy o Nim, a tutaj sugeruje się Jego obecność, wszechobecność w świecie. To właśnie ta bliskość tych pytań u Akwinaty jest tutaj nad wyraz intrygująca i ciekawa, $i$ to ona sprowokowała mnie do poszukiwania adekwatnej odpowiedzi na 
pytanie dotyczące relacji Nieskończonego z rzeczą skończoną, a zatem także z konkretnym człowiekiem.

Sam Akwinata ową „bliskość” określa jako „bycie Boga w rzeczach” (existentia Dei in rebus). Uprawnionym jest jednak, tak sądzę, użycie tutaj terminu „bliskość”, gdyż jak można dostrzec w kontekście wypowiedzi samego Tomasza, owo „bycie” (existentia) w rzeczach, może przyjać formę wręcz osobowego kontaktu i nawiązania wzajemnej przyjaźni między osobą Boga i osobą człowieka. Dokonuje się to w kontekście sposobu „bycia Boga w rzeczach" określanego przez Akwinatę mianem praesentia (obecność). Nie wybiegając jednak zbytnio do przodu, pochylmy się nad samym tekstem kwestii 8, a zwłaszcza artykułem 3: Utrum Deus sit ubique per essentiam, praesentiam et potentiam (Czy Bóg jest wszędzie swoją istota, obecnościa, potęga [moca]). Tutaj Akwinata prezentuje aż trzy sposoby „bycia Boga w rzeczach", jakby mówił o trzech różnych drogach, którymi dokonuje się owo „zbliżenie” nieskończoności ze skończonościa, i taką przyjmuje formę, przejawiając bogactwo pełni swojego Bytu. Existentia in rebus odnosi się do bytów skończonych, ponieważ słowo res (rzecz), i określenie in rebus (w rzeczach), jest w tym wypadku na tyle pojemne, że obejmuje wszystkie rzeczy istniejące, $w$ tym rzeczy świata widzialnego i niewidzialnego, także anioła i człowieka, całą stworzoność wszystkich rzeczy, odróżnionych (oddzielonych) od Boga.

Stwierdzenie Akwinaty, że Bóg powszechnie jest we wszystkich rzeczach przez „istotę”, „obecność”, ,potęgę” (moc), zdaje się, że przyjmuje on na kanwie innej wypowiedzi Pseudo-Dionizego Areopagity, że „Duchy niebieskie składają się z istoty, siły i działania (caelestes spiritus dividuntur in essentiam, virtutem i potentiam)" ${ }^{24}$. Tutaj wydaje się, iż Akwinata stosuje trójpodział bytu, a co zdaje się według niego ujawniać szczególnie u istot żywych (w aniołach, człowieku) i w ich działaniu. Niektórzy tomiści (np. P. Semenenko ${ }^{25}$, Wł. Kwiatkowski ${ }^{26}$ ) twierdzili, że św. Tomasz, choć idzie z reguły wiernie za Arystotelesem, czasami mówi także o trzecim składniku wszechrzeczy, to jest o sile. Choć powszechnie przyjmuje, że między substancją a przypadłością, między materią a formą, nie ma nic pośredniego, to jednak napotkać możemy u Akwinaty (zapewne jako spuścizna po Pseudo-Dionizym) ów trójpodział, a co - w pewnej mierze - ma tutaj swoje znaczenie. Co się bowiem tyczy duszy ludzkiej, św. Tomasz, idąc za Pseudo-

${ }^{24}$ Psuedo-Dionizy Areopagita, Hierarchia niebieska, rozdz. 11, 2 (PG 3, 284), cyt. S. Th., I, q. 77, a. 1, sed contra.

${ }^{25}$ P. Semenenko, Credo. Chrześcijańskie prawdy wiary, Kraków 1885, s. 159-162.

${ }^{26}$ Wł. Kwiatkowski, Św. Tomasz i scholastyka $w$ oświetleniu o. Piotra Semenenki, Nakładem Księży Zmartwychwstania Pańskiego, Kraków 1936, s. 11-128. 
-Dionizym Areopagita, rozgranicza istotę duszy (essentia), następnie to, co się odnosi do jej siły, czyli władzy (ad virtutem sive potentias eius), a na trzecim miejscu to, co się odnosi do działania (operatio). Władzę Tomasz nazywa, w tym wypadku (q. 77, a. 1), siłą (virtus), która jest odróżniona od jej działania (operatio), gdyż każda rzecz nie działa przez swoją istotę, ale za pośrednictwem swoich władz. Te jednak, aby rzeczywiście działały, czyli wychodziły ku urzeczywistnieniu (do aktu), potrzebują jakiejś zewnętrznej lub wewnętrznej siły. Działanie duszy, jako akt przypadłościowy, jest zatem tym urzeczywistnieniem istoty duszy (aktem), gdzie władza stanowi narzędzie, siłę. Jedynie Bóg działa bezpośrednio swoją istotą, bo u Niego nie ma żadnej złożoności ani przypadłości, ale wszystko jest zasadnicze (istotne), także działanie.

To rozróżnienie jest pożyteczne dla lepszego zrozumienia obecności Boga $\mathrm{w}$ świecie. Jest on bowiem obecny we wszystkich stworzeniach na trzy sposoby: essentialiter, potentialiter i praesentialiter, a zatem, zgodnie ze wspomnianym już tutaj rozróżnieniem tych trzech aspektów przez Pseudo-Dionizego Areopagitę, przez istotę, potęgę i obecność. Przyjrzyjmy się teraz dokładniej tym trzem zagadnieniom obecności Boga w rzeczach, co z punktu widzenia rozwoju myśli należy do najbardziej ciekawych, choć kontrowersyjnych zagadnieńn ${ }^{27}$. Sam Tomasz jest tego świadomy, gdyż gdy zaczyna mówić o obecności Boga w świecie, najpierw przedstawia trudności związane z ideą Jego „bycia w rzeczach”. Przede wszystkim przedstawia pogląd manichejczyków, którzy twierdzili, że władzy Boga podlegają jedynie istoty duchowe i bezcielesne, natomiast wszystko, co widzialne i cielesne, podlega władzy czynnika przeciwnego. Siła (władza) Boga nie sięga więc świata stworzonego, który jako dotknięty materia, rządzony jest przez pierwiastek zła. Opinii tej Akwinata przeciwstawi twierdzenie, że Bóg jest obecny w rzeczach per potentiam. Materia bowiem nie jest przesiąknięta pierwiastkiem zła, jest ona jako byt czymś pomyślanym i uczynionym przez dobrego Boga. Tym samym wskazuje na moc istoty Boga, która jest tym, co ją poprzedza i jest od niej pierwotniejsza. Wszystko, co istnieje, pochodzi od stwórczej potęgi (mocy) Boga.

Drugą trudność Tomasz dostrzega zaś w poglądzie, że opatrzność Boża nie rozciagga się na świat. Przywołany jest tutaj następujący werset z Księgi Hioba (Hi 22, 14): „Czy Bóg wie cokolwiek, czy spoza chmur może sądzić? Chmura - zasłoną; nie widzi. Po sferach niebieskich On chodzi”. Oto przykład deizmu, uznającego istnienie Boga jako stwórcy wszechświata, ale od-

${ }^{27}$ O obecności Boga w świecie mówiło wielu filozofów i teologów. Za całkowitą negację obecności opowiedział się F. Nietzsche, głosząc „śmierć Boga”. Współcześnie człowiek zdaje się nie odczuwać obecności Boga w świecie. 
rzucającego przekonanie, że Bóg ma moc ingerowania w losy świata i człowieka. Opinii tej św. Tomasz przeciwstawia twierdzenie, że Bóg jest we wszystkim swoją obecnością. Człowiek może rozpoznać Boga w działaniu swojej duszy, poznaniu i miłowaniu.

Trzecia trudność wyszczególniona przez Akwinatę dotyczy głoszenia poglądu, że Bóg nie stworzył wszystkiego bezpośrednio, stworzył zaś tylko pierwsze stworzenia, a te dopiero stwarzały pozostałe. Mamy tutaj do czynienia ze swoistym typem pośrednictwa w stwarzaniu, a istota rzeczy pojawiała się jako produkt owego wtórnego aktu stworzenia. Opinii tej Tomasz przeciwstawia twierdzenie, że Bóg jest we wszystkim osobiście per essentiam. Bóg w każdej rzeczy jest jako ten, który sprawia jej istnienie. Przejdźmy teraz do dokładniejszej analizy poszczególnych typów obecności Boga w świecie.

\subsection{Bycie Boga $w$ rzeczach przez istotę (per essentiam)}

Mimo sugestii wynikającej z nazwy używanej tutaj przez Akwinatę, bycia Boga w rzeczach per essentiam, nie należy sądzić, że Bóg jest w rzeczach jako ich istota. Należy dokładnie rozróżnić dwie płaszczyzny: substancjalną i przyczynową. Bóg jest transcendentny i przewyższa wszystkie stworzenia pod względem swojej natury, obecny jest jednak na płaszczyźnie przyczynowości jako sprawca istnienia wszystkich bytów. „Bóg jest we wszystkich rzeczach nie jako część ich istoty, ani też jako ich przypadłość, ale tak jak twórca jest obecny w dziele, którego dokonuje"28. Bóg ze swojej istoty jest samym istnieniem, dlatego właściwym skutkiem tak pojętego Boga jest dla Tomasza to, że jest przyczyną sprawczą rzeczy stworzonych. Stwarzanie, powoływanie do istnienia jest swoistym skutkiem własnym Boga, w którym istota i istnienie są tym samym. Effectus proprius, swoistym właściwym skutkiem działania Istnienia nieskończonego (Boga) jest stwarzanie rzeczy skończonych, ich powołanie do „istnienia stworzonego" (esse creatum ${ }^{29}$. Można tu podać podobne przykłady ze świata rzeczy, na przykład właściwym skutkiem ognia jest palenie się, śpiew właściwym skutkiem śpiewaka, czy też budynek budowniczego. Tomasz precyzuje jednak dalej: „Bóg wywołuje w rzeczach taki właśnie skutek [istnienie stworzone] nie tylko wtedy, gdy po raz pierwszy zaczynają istnieć, ale dopóty, dopóki są podtrzymywane

${ }^{28}$ S. Th., I, q. 8, a. 1c (korzystamy tutaj z thumaczenia zawartego w: Tomasz z Akwinu, Traktat o Bogu. Summa teologii, kwestie 1-26, przekład i komentarze G. Kurylewicz, Z. Nerczuk, M. Olszewski, Wydawnictwo Znak, Kraków 1999).

${ }^{29}$ Tamże. 
$\mathrm{W}$ istnieniu (in esse conservantur)" ${ }^{\prime 30}$. W tym miejscu posłuży się jednym ze swoich ulubionych porównan, aby jeszcze bardziej naświetlić obecność Boga w stworzeniu: „Na przykład światło w powietrzu spowodowane przez Słońce trwa, dopóki powietrze jest oświetlone"31. Bóg jest tak długo obecny w rzeczy stworzonej, jak długo ma ona istnienie. Intuicja Tomasza wyraża się więc $\mathrm{w}$ idei stworzenia, darowania istnienia. Wszystko, co istnieje, ma swoją przyczynę w Bogu, który udziela istnienia. Oto decydujące sformułowanie: „Istnienie jest tym, co najbardziej wewnętrzne w każdej rzeczy i co tkwi we wszystkim najgłębiej, gdyż jest formą w stosunku do wszystkiego, co jest w każdej rzeczy" (Esse autem est illud quod est magis intimum cuilibet, et quo profundius omnibus inest: cum sit formale respectu omnium quae in re sunt) $)^{32}$. Tym samym mamy tu podstawowe „wyczucie”, kim jest Bóg: jest dawcą istnienia. „Wyczucie” bliskości Boga, gdyż poza intelektem, odkrywającym tę prawdę, decydujące będzie w konsekwencji przylgniecie do niej naszej woli (assensio voluntatis), po to, aby nie pozostała ona na poziomie czystej poznawalności, ale przyjęta została aktem zawierzenia Bogu Żyjącemu (osobowemu). To jednak dobitnie można będzie zobaczyć dopiero w trzecim sposobie bliskości-bycia Boga w rzeczach, per praesentiam. Tutaj pozostajemy na poziomie spekulacji intelektualnej, filozoficznej.

U św. Tomasza ciagle pojawia się ten podstawowy motyw: idea stworzenia jako udzielanie istnienia. Można tu również powiedzieć, że jest to w pewnym stopniu najkrótsze sformułowanie filozofii (teologii) negatywnej: człowiek nie osiaga do końca poznania tego, kim jest ów nieskończony Stwórca, będący samoistnym Istnieniem, ale to, że jest, gdyż udziela rzeczom istnienia. Tego, co w nich najintymniejsze, najbardziej podstawowe i sekretne. Boga poznaję w tym obdarowaniu i staje się On mi coraz bliższy przez coraz dokładniejsze poznanie Jego sprawczości w stwarzaniu rzeczy, świata, mnie samego. Boga jako Ipsum Esse Subsistens, poznaję jako oddalonego od wszystkiego, co widzialne, poznaję Go w skutkach Jego działania, w rzeczach, które są obdarowywane istnieniem. Drogę zaś ustalenia przyczyny istnienia rzeczy, ich causa efficientis, przyczynę sprawcza, poznaje się drogą separacji, czyli tworzenia sądów egzystencjalnych („,coś jest”, „to jest”, „ktoś jest”), pokazujących, że wszystkie byty mają istnienie, ale jest to istnienie przygodne, niekonieczne, nic, co samo w sobie jest istnieniem. Sam Bóg pozostaje Istotą przewyższająca wszelkie istnienie skończone, żeby więc coś mogło istnieć przygodnie, musi otrzymać istnienie od bytu, który sam jest istnieniem, i w nim musi mieć swoje źródło. Parafrazując wy-

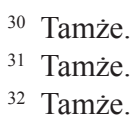


powiedzi Tomasza, można powiedzieć, że to, że człowiek „pali się” ogniem istnienia, zawdzięcza się Bogu, który jest istnieniem samoistnym, samym „ogniem”. To, że człowiek może być „światłem” przed ludźmi, zawdzięcza Bogu, który jest samą „światłością”, słońcem świata. W ten sposób Akwinata łączy bezpośrednio problem separacji z istnieniem Boga. Jeżeli w bycie najważniejsze jest istnienie i ono, jak pisze tu Tomasz, jest w nim ,najgłębiej" w rzeczywistości, to wraz z nim zmienia się rola abstrakcji w procesie poznania. Abstrakcja, która jest procesem tworzenia pojęć, w którym wychodzi się od rzeczy jednostkowych, konkretnych, a dochodzi się do pojęć najuboższych w treść, ale o najszerszym zakresie (na przykład byt), nie ma tu miejsca. W tym sensie ,istnienie” jest niepojęciowalne. Tym, co jest w stanie uchwycić istnienie, nie jest abstrakcja i tworzenie przez abstrakcję pojęcia, ale bezpośrednie doświadczenie zmysłowe i sąd egzystencjalny, który pozwala uchwycić istnienie. $\mathrm{W}$ tym sensie problem poznawalności istnienia wszedł w kontekst kontemplacji przyrodzonej, gdzie zatrzymanie się nad tym, „co jest”, wpatrzenie się w rzeczy, jest pewnym zetknięciem się z istnieniem, jego ujęciem poprzez sąd egzystencjalny. Tutaj kontemplacja filozoficzna nieuchronnie przechodzi w kontemplację nadprzyrodzoną. Jest więc tak, jak pragnie tego Marek Szulakiewicz w swojej książce Religia i czas, aby doświadczenie świata nie było obce doświadczeniu religijnemu ${ }^{33}$.

Oczywiście bycie Boga w rzeczach jest najbardziej czytelne wtedy, gdy oczy przyrodzonego kontemplatyka nie są zaabsorbowane tym, co rozprasza, a sama rzecz nie posiada żadnej zmazy (macula). Tomasz przy końcu artykułu 1, kwestii 8 , odnosząc się do zagadnienia bycia Boga w demonach, powie: „widać [w nich] naturę, która jest od Boga, i zniekształcenie spowodowane winą, które nie pochodzi od Boga" ${ }^{34}$. Nie wchodząc tutaj w szczegóły, możemy powiedzieć, że w ten prosty sposób Akwinata wypowiada się o trudnościach w rozpoznaniu prawdy o byciu Boga w świecie per essentiam z powodu istnienia zła i grzechu.

\subsection{Bycie Boga w rzeczach przez potęgę (per potentiam)}

Sprawa rozważenia bycia-obecności Boga w rzeczach per potentiam jest bardziej skomplikowana, gdyż jej Tomasz poświęca mniej miejsca. Trzeba tutaj po części powrócić do odniesień, które zostały tu poczynione odnośnie do „siły” jako składnika wszystkich bytów. Jest to składnik decydujący o ruchu stworzeń, a w konsekwencji o działaniu (opertatio). Rzeczy-

33 Por. M. Szulakiewicz, dz. cyt., s. 197-198.

34 S. Th., I, q. 8, a. 1, ad 4. 
wiście jakby przeczuwając trudności czytelnika w zrozumieniu tej kwestii, powtórzy w artykule 2 zagadnienia 8 (Pars Prima) to, co powiedział Pseudo-Dionizy Areopagita: „Bóg jest w każdym miejscu, co znaczy: wszędzie. [...] jest tak, jak we wszystkich rzeczach, jak więc jako dający im istnienie, siłę, i działanie" (Deus est in omni loco, quo est esse ubique. [...] Sicut est in omnibus rebus, ut dans eis esse, et virtutem, et operationem) ${ }^{35}$. Trzymając się tekstu, możemy zapytać, co to oznacza, że Bóg daje rzeczy siłę? W jaki sposób jest On tutaj obecny? W nakreślonych uprzednio zdaniach ukazaliśmy, że według Akwinaty składnikiem bytu jest także siła (virtus, potentia). Bóg, który udziela istnienia, jest też przyczyną istnienia samego miejsca, w którym byt spełnia swoją bytową rolę. Słowa: sic enim est in omni loco, ut dans ei esse et virtutem loctativam (,w ten sposób [Bóg] jest w każdym miejscu, dając mu istnienie i siłę udzielania miejsca") ${ }^{36}$, wskazują na możliwość urzeczywistnienia swojego istnienia, realizacji i spełnia tego, co w istnieniu zostało przez Boga złożone, czyli owa zdolność podołania temu darowi w konkretnym urzeczywistnieniu. Byt posiadający istnienie, „umieszczony w miejscu”, staje ze swoją siłą naprzeciw „podołania rzeczom wielkim lub małym" "37, posługując się udzieloną siłą. Siła (virtus) niejako więc rządzi bytem (rzecza), powiększając swoje istnienie lub je zmniejszając. Przez siłę dokonuje się więc rozwój, ona daje życie, czyli możliwość przyjmowania w miejscu nowych form. Stąd prawem esse (istnienia) jest rozwój, przemiana, stawanie się. Termin loco (miejsce) oznacza tu zarówno przestrzeń, jak i czas dla podjętego realizowania tego, czym byt już jest, i tego czym może być. Sam Tomasz mówi, że „w miejscu” ma się zarówno „czas do ciagu następujących po sobie momentów", habet tempus ad successiva, a także „miejsce do stałych punktów wyznaczających jego położenie”, habet locus ad permanentia ${ }^{38}$. Akwinata, operując tymi terminami, chce ukazać dynamizm czasu i przestrzeni, w których siła tkwiąca w esse, w istnieniu, może się realizować. Loco to „miejsce”, przestrzeń i czas udzielone przez Boga do urzeczywistnienia siebie. Nie mamy jednak tu jeszcze mowy o rzeczywistym urzeczywistnieniu, ale o potencjalności takiego urzeczywistnienia, o sile, która również jest darem samego Boga. Oczywiście owa siła w różnych bytach jest inna, może to być siła materialna, czy też siła duchowa, różnie w zależności od bytu, któremu przysługuje istnienie. Tomaszowi nie chodzi też o jakieś człony czasu czy poszczególne części miejsc działania, ale o czas i przestrzeń daną jako taką dla realizowania i urzeczywistnienia sie-

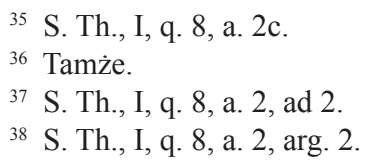


bie, swojej siły materialnej czy duchowej, zależnie od rodzaju bytu. W przypadku człowieka można mówić o sile na poziomie ściśle zmysłowym, czyli o sile materialnej, także o przyrodzonej sile poznania, sile czucia i pożądania, sile chcenia, czyli sile woli. To tymi siłami człowiek realizuje siebie, siłę swojej osoby. W osobie jednoczą się niejako owe wszystkie wymienione siły natury, którymi osoba rozporządza, w tym czasie i w tym miejscu, które udzielone jest człowiekowi przez Boga dla wypełnienia zadania ,udzielania miejsca (istnieniu)", czyli powiększania (bądź zmniejszania) swego esse. Pytanie, które, mówiąc obrazowo, zadać może Bóg u kresu, u celu realizacji zadania: ile zyskałeś istnienia, „człowieka w człowieku”, owych ewangelicznych talentów. Tomasz powie językiem filozoficznym, że chodzi tu o to, czy „rzecz jest w całości w jakimś miejscu” (quod est totum alicubi) $)^{39}$. „Być całym w miejscu”, takim jest Bóg, zaś człowiek jest „całym”, gdy jest urzeczywistniony w pełnym swoim człowieczeństwie, wydobył niejako na zewnątrz całą swoją potencjalność i ją doprowadził ad ultimum, do końca. Podołał rzeczy wielkiej, zrealizował swoją potencjalność, zapełnił miejsce, swoją przestrzeń i czas, wypełniając ją swoim esse.

Widzimy tutaj ogromne znaczenie, jakie ma owo bycie Boga $\mathrm{w}$ bycie przez siłę (moc, potencję). Zgodnie z sensem wypowiedzi Tomasza, widzimy jak to, co przyjmuje istnienie, jest w możności w stosunku do swojego istnienia (in potentia esse). Mamy więc tu ową zdolność (virtus), która będąc związana z przydzielonym „miejscem”, wskazuje, że nie ma już w sobie żadnych przeszkód do bycia, gdyż „ma miejsce”. Tutaj ogrania się ów centralny problem złożenia z możności jako istoty i aktu, jako urzeczywistnienia. Możność (potenita) to także pojęcie proste niedające się definiować. Mamy tu do czynienia $\mathrm{z}$ pewnym ruchem, pojętym $\mathrm{w}$ bardzo szerokim znaczeniu i obejmującym wszelką zmianę. Tutaj Bóg jest przyczyną sprawczą, ale dając człowiekowi, jako stworzeniu rozumnemu, szczególne miejsce (loco), wprowadza go w obieg swojej własnej sprawczości. Bóg z jednej strony obdarowuje stworzenia siłą działania, aby działały ku dobru. Możność ta, potentia, sprawia, że człowiek jest także niejako sam z siebie zasadą własnych czynów, własnego urzeczywistnienia. Oznacza to, że człowiek jako stworzenie rozumne, został powołany do tego, aby dochodzić, i to własnym wysiłkiem, do zbudowania w sobie tej doskonałości, którą sam został obdarowany. $\mathrm{W}$ ten sposób uczestniczy (participatio) w Bożym panowaniu (potędze, opatrzności). Człowiek ma swoje „miejsce”, a jest to miejsce jego wolności, gdzie Bóg pozostaje pierwszą przyczyna, darując mu własną przestrzeń rozwoju. Ogólnie mówiąc, dochodzimy tu do przekonania, że zmiana nie może dziać się sama i że wobec tego usprawiedliwiona jest teza,

39 S. Th., I, q. 8, arg. 3. 
iż cokolwiek znajduje się w ruchu i posiada siłę ruchu, porusza się dzięki czemuś innemu. Wszystko przyporządkowane zostaje możliwości urzeczywistnienia, skierowania do bycia, do aktu. W ten sposób można powiedzieć, iż mamy pewne ustopniowanie bytu: istnienie, potencja i akt, urzeczywistnienie, dokonywujące się drogą rzeczywistego działania (operatio). Przejście od bytu możliwego do bytu rzeczywistego, przejście z jednego sposobu istnienia do drugiego, a w konsekwencji osiagnięcia pełni owej „całości”. Warto też jeszcze raz podkreślić, że potencjalność, o której tu mowa, a która nie jest tym samym w człowieku, co istota duszy ${ }^{40}$, otwiera się także na całą zagadkowość czasu i istnienia czasowego jako takiego. Tu chwila, moment, gdyż także dla Tomasza czas jest tutaj ,jak ciąg następujących po sobie momentów" (tempus ad successiva), nie jest możliwa bez istnienia przeszłości i przyszłości. Sam fakt, że Tomasz używa tutaj terminu tempus, sugeruje, że ma na myśli człowieka i o człowieku tutaj mówi. Czas bowiem nie istnieje w świecie zewnętrznym, a jedynie w ludzkim intelekcie. Ruch dokonuje się w świecie ciał, jednak liczenie tego ruchu jest sprawą samego umysłu. Tomasz, powołując się na Arystotelesa, powie, że nie byłoby duszy, nie byłoby czasu ${ }^{41}$. W ten sposób czas jest miarą tej rzeczywistości, jaką jest akt nierealizujący jeszcze całej potencjalności. Człowiek (dusza) mierzy tę rzeczywistość przez liczenie następstw, owych przejść od tego, co „przed”, do tego, co „po". Akwinata przyjmuje więc tutaj definicję czasu Arystotelesa: Tempus est numerus motus secundum prius er posterius (czas to liczba ruchu w jego „przed" i „po" ${ }^{42}$. W tym też sensie narodzenie czasu dokonuje się w „miejscu”, gdzie potencjalność człowieka dokonuje kolejnego przechodzenia od momentu ,przed” do momentu „po”. Istnienie, w tym znaczeniu, jest trwającym w czasie stawaniem się. Ten czas jest stale otwarty na przyszłość, rozumianą jako horyzont absolutnego spełnienia. Z perspektywy losu konkretnego człowieka taki czas jest czasem zawsze możliwej nadziei. Nic dziwnego, że nadzieja, droga ku ostatecznemu spełnieniu, tak naprawdę jest inną twarzą czasu. To istnieniu potrzebny jest czas i nadzieja. Istnieniu, któremu ciagle potrzebne jest nowe ustawienie, nowe wypełniające się ciagle nadzieją ,miejsce”. Tutaj to, co człowiek może, przechodzi w urzeczywistnienie (akt). In potentia esse są to sposoby istnienia rzeczy skończonych, Bóg nie może inaczej, jak tylko być in actu esse.

Bycie Boga w rzeczach per potentiam Akwinata obrazuje, odwołując się do obrazu króla, który swoją potęgą (władzą) jest obecny w całym kraju, nad którym rozciaga się jego panowanie, chociaż nie wszędzie jest On oso-

\footnotetext{
40 Por. S. Th., I, q. 77, a. 1.

41 Por. In I Sent., d. 19, a. 2, a. 1.

42 Por. Arystoteles, Fizyka, IV, c. 12, 221 b, 3-5. U Tomasza por. In Phys., IV, lect. 2.
} 
biście obecny. Substancjalnie, czyli cieleśnie nie jest obecny wszędzie. Bóg jest zatem obecny w świecie przez swoją niezmierzoną moc objawiającą się w sile rzeczy, tak bytów cielesnych, jak i duchowych. Jego moc widoczna jest szczególnie w bytach duchowych, szczególnie bowiem to one, rządząc sobą według udzielonej im przez Boga siły, mogą wpływać na inne stworzenia mniej doskonałe. Jeżeli bowiem Bóg udziela bytom swojego istnienia, to także tej mocy, aby one, mając własne działanie, realizowały Jego opatrznościowy plan wobec świata.

\subsection{Bycie Boga w rzeczach przez obecność (per praesentiam)}

Bóg jest we wszystkich bytach także „przez obecność” (per praesentiam), którą św. Tomasz rozumie na dwa sposoby: w znaczeniu szerokim określanym in conspectu oraz wąskim nazywanym przez Akwinatę „obecnością substancjalną”, czy „istotową”, sprowadzającą się do bezpośredniej jego bliskości. Pierwszy aspekt realizuje się (w znaczeniu szerokim), w ten sposób, że wszystkie byty są ,odkryte i jawne oczom” Boga, który ma o nich doskonałą wiedzę. Posługując się tutaj zwrotem in conspectu, który oznacza „bycie jawnym”, Akwinata wskazuje, że Bóg jest w rzeczach, ponieważ widzi każdą z nich, a poznanie bytu jest tutaj bezpośrednie. Takie poznanie przysługuje Bogu bez jakichkolwiek warunków czy założeń, wynika z samej istoty Boga. Tomasz daje tutaj przykład gospodyni, która gdy jest w domu, „ma wszystko na oku”, „w zasięgu swego wzroku”, chociaż nie jest swoją osobą w każdym jego zakątku.

Drugi sposób bycia Boga per praesentiam, ów będący „obecnością istotową", ujawnia się jedynie w stworzeniu rozumnym, o ile ono aktualnie poznaje i miłuje Boga. Tomasz powie, że taka bliskość Boga jest właściwa działaniu duszy, jej poznaniu i jej pożądaniu (chceniu), ,zgodnie z tym, że poznane [przedmiot poznania] jest w poznającym, i pożądane [rzecz upragniona] w pożądającym" (secundum quod cognitum est in cognoscente, et desideratum in desiderante $)^{43}$. Jest to więc obecność Boga jako „przedmiotu działania będącego w działającym”. „W ten zatem sposób Bóg w szczególności jest w stworzeniu rozumnym, które Go poznaje i kocha rzeczywiście lub jest do tego zdolne. Ponieważ jest to dane stworzeniu przez łaskę, to twierdzi się, że tak właśnie Bóg jest w świętych przez łaskę" (Hoc igitur secundo modo, Deus specialiter est in rationali creatura, quae cognoscit et diligit illum actu vel habitu. Et quia hoc habet rationalis creatura per gra-

43 S. Th., I, q. 8, a. 3c. 
tiam, dicitur esse hoc modo in sanctis per gratiam $)^{44}$. W taki sposób Boga może „ujaćc” człowiek przez poznanie i miłość, gdy zostanie dana mu łaska. Człowiek zaś jest capax gratiae ${ }^{45}$, a realizuje się on wtedy, gdy dzięki łasce wiary dochodzi do poznania pierwszej prawdy, i dzięki łasce miłości osiaga pierwszą dobroć.

Trzeba przyznać, że sam Tomasz w tym momencie odsyła do innych fragmentów swojej Sumy, gdyż tutaj nawarstwia się wiele nowych kwestii. Przede wszystkim możliwość relacji osobowej z Bogiem (relacji wręcz przyjacielskiej), czy także niewspółmierność darowanej łaski, która jest już otrzymaniem „nowego życia”, „życia, które jest wieczne”. Te miejsca to: Pars Prima, q. 43, a. 3, gdzie Tomasz pyta: „Czy niewidzialne posyłanie osoby Boskiej odbywa się jedynie ze względu na dar łaski uświęcającej?”, a także z Prima Secundae, q. 109, a. 1 i 3, gdzie stawiane są także ważne pytania: „Czy człowiek może bez pomocy łaski poznać jakąś prawdę?”, oraz „Czy człowiek może bez pomocy łaski, samymi tylko siłami naturalnymi, kochać Boga nade wszystko?”. Nie miejsce tutaj na szczegółową analizę. Wystarczy tutaj jedynie wspomnieć, że św. Tomasz widzi w relacji osobowej z Bogiem niebywały, przewyższający wszelkie oczekiwania, dar Boga. „Bóg bowiem nie tylko jest w stworzeniu, ale coś więcej: mieszka w nim jak w swojej świątyni" 46 . Marie-Dominique Chenu, komentując myśl Akwinaty o tajemnicy relacji człowieka z Bogiem, tak powie:

Już w zwykłej rozmowie, w której partnerem jest drugi człowiek, odkąd tylko zaczynamy się posługiwać słowami, potrzebne jest minimum «zaufania», będące elementarnym warunkiem dialogu [...]. Kiedy partnerem jest Bóg, do tej psychologicznej konieczności dochodzi jeszcze radykalny wymóg tkwiący $\mathrm{w}$ istocie mojego ducha: musi on być wewnętrznie podniesiony do poziomu tego partnera, którego życie może być dla mnie tylko i wyłącznie całkowitą tajemnicą. Wiara jest wówczas we mnie wzniesieniem mojego rozumu do tajemnicy tego nadbytu, który mówi do mnie ${ }^{47}$.

Łaska przychodzi tu z zewnątrz, i jest co prawda elementem obcym dla pewnego wewnątrzświatowego układu, ale ma siłę przemienić ten układ. Dobro jako łaska rozlewa się i rośnie w samym człowieku, a przez niego także

44 Tamże.

45 Por. M. Mróz, Spór o człowieka. Kilka uwag na kanwie nauki św. Tomasza z Akwinu o pośrednictwie przyczyn stworzonych w rzqdach Bożej Opatrzności, w: J. Nagórny, J. Gocko (red.), Spór o człowieka - spór o przyszłość świata, KUL, Lublin 2004, s. 163-175.

46 S. Th., I, q. 43, a. 3c.

47 M.-D. Chenu, Św. Tomasz i teologia, Znak, Kraków 1997, s. 38. 
w świecie. Zatem można mówić tu o dobru obecnym i działającym w przestrzeni i w czasie ludzkim.

Tomasz przywiązuje też wielką wagę do powiedzenia w tym kontekście nowej rzeczy o samym Bogu. Jest On tutaj nie tylko Bogiem Stwórca, podstawą wszelkiego bytu (istnienia), ale jest prawdziwie świadomym siebie myśleniem, które zna nie tylko siebie, ale także i człowieka, także mnie konkretnie. Ale nie tylko zna, również i kocha, On, który jest Stwórca, a jako Stwórca jawi się jako Miłość. I że to przez Niego i ja mogę myśleć i kochać - po prostu włącza mnie do swojej przestrzeni wolności, wolności własnego bytu. Obiektywizuje i wyzwala mnie jako byt samodzielny, osobowy. On, byt, który podtrzymuje wszystko w istnieniu i wszystko obejmuje (Deus est esse omnium), jako Osoba zaprasza mnie do relacji i przyjaźni z sobą samym. Czy człowiek mógł oczekiwać czegoś więcej, większej obecności i zbliżenia nad to?

\section{Religia rozumu - religia relacji (miłości): chwała Boża w stworzeniu rozumnym}

O św. Tomaszu mówi się, że jest przedstawicielem skrajnego scholastycznego intelektualizmu. Analizy tutaj uczynione wskazują jednak, że jego wielkość jest zupełnie odmiennego formatu. Opozycja bliskość, oddalenie Boga, byt czy relacja, nie są u niego alternatywą rozłączną: albo-albo, lecz raczej wyróżnikiem komplementarności tych spojrzeń. Zapewne Akwinata odzwierciedla pewne napięcie pomiędzy religią rozumu i religią relacji (osobowej). Widać to w jego analizie bycia Boga w rzeczach bardzo dobitnie, ale nie można twierdzić, że o żywej bliskości z Bogiem zapomina. Zrozumienie jest sferą ludzkiego umysłu, ale dokonuje się równocześnie przy współudziale relacji miłości. Obecność-bycie Boga w świecie to spotkanie Nieskończonego ze skończonością, spotkanie pełne szacunku i podjętej współpracy, nawet już w pierwszej fazie wzajemnego zrozumienia prawdy o sytuacji początku, gdzie Bóg jest Stwórca, świat, rzeczy, człowiek posiada w darze otrzymanego istnienia. Potem sytuacja zaczyna się coraz bardziej krystalizować, gdy człowiek jako stworzenie rozumne zostaje zaproszony do zajmowania „miejsca”, czyli w pełnej wolności urzeczywistnienia siebie, w przestrzeni i czasie darowanym przez Boga. A jakże nie zadziwić się nad owym zaproszeniem do osobowej relacji przyjaźni i miłości. Wszystkie te trzy tory rozumowania, które przedstawia Akwinata, bycie Boga w rzeczach per essentiam, potentiam i paesentiam z konieczności prezentowane są jakby były osobnymi sekcjami kolejnych podejść i działań. Jest to jednak jedno, wyjątkowe bycie Boga w świecie. 
Bycie Boga w rzeczach, pojmuje się łatwo, stosując kategorię „obecność", jest ona jednak bardziej fenomenologiczna niż metafizyczna. Niemniej jednak użycie tej kategorii wydaje się uprawnione w momencie, gdy przyjmuje się racjonalność i realność rzeczy. „Bycie”, „bytność”, to znajdowanie się gdzieś, przebywanie, a zatem realna obecność, wszechobecność Boga w rzeczach (omnipraesentia). Omówienie przez nas tutaj kwestii 8 Sumy teologii było podjęciem tematu, który Akwinacie towarzyszy przez całe życie. Wybrany przez nas tekst nie wyczerpuje całości zagadnienia, jest jednak na tyle reprezentatywny, że ukazuje w pewnym skrócie całość Tomaszowego myślenia. Jest to zestawienie Boskiej transcendencji z immanencją Boga, nieskończoności ze skończonością, co zawsze w analizach filozoficznych wywołuje niemałe zamieszanie. Pogodzenie tych dwu biegunowych, jakże przecież odległych rzeczywistości w jednej spójnej koncepcji jest nie łatwą sztuką. Nie zapominajmy także, że Akwinata chciał swoje rozwiązanie zespolić ze swoją wiarą chrześcijańską i ją tutaj przede wszystkim ukazać. Łatwo można było tutaj wpaść w pułapkę panteizmu, czy innych teorii, bądź całych doktryn, odbiegających od prawdy chrześcijańskiej zawartej w Objawieniu. Zapewne kluczowe jest tutaj pojęcie obecności przez istotę (per essentiam). Ono wyznacza udział Boga w stworzeniach. Tomasz określił go bez naruszenia przekonania i wyższości natury Boskiej nad naturą innych bytów. Bycie jednak Boga per potentiam (przez moc, potęgę) oraz per praesentiam wyznacza już inną przestrzeń odniesień, które jawią się jako osobowe i relacyjne. W obecności Boga w bycie rozumnym per potentiam podkreślona jest wolność potencjalności i działania, w tej per praesentiam fakt nawiązania więzi osobowych relacji.

\section{Zamiast zakończenia: implikacje pedagogiczne}

Warto na koniec podkreślić fakt, że mimo iż w centrum kwestii 8 jest cały czas Bóg, Akwinata z wielką atencją przygląda się rzeczom, a zwłaszcza stworzeniu rozumnemu. To spojrzenie zostanie przez niego rozwinięte w traktacie o człowieku ${ }^{48}$. Konsekwencja, jaka wypływa z całości przedstawionych analiz, jest jedna: transcendentny Bóg pozostaje takim, ale jest on przez darowane istnienie bliższy bytom niż one same sobie. To stwierdzenie można przytaczać tym, którzy twierdzą, że Tomasz z Akwinu o Bogu mówi jako o kimś, kto z człowiekiem nie ma wiele wspólnego.

Z punktu widzenia pedagogiki jest to ważne, gdyż otwiera wielką pespektywę wychowania do „wolności do uwagi” i wychowania do „wolności

${ }^{48}$ Por. S. Th., I, q. $75-84$. 
pytającej”. Na ten temat zwrócił już uwagę L. Giussani w swojej książce Zmyst religijny ${ }^{49}$. Tomasz z Akwinu odsyła bowiem z wielką mocą do rzeczywistości świata, do wglądu w to, co istnieje jako stworzone, bez obawy, że człowiek będzie miał za wiele pytań. Pytań może być właśnie za mało. Tak bardzo myśl współczesna koncentruje się na konstrukcjach myślowych człowieka, że nie zauważa realności świata i „mowy Boga” w tejże realności. Wychowanie „do uwagi” to nic innego, jak przyjęcie propozycji dawanej przez rzeczywistość rzeczy, i to w sposób otwarty, bez zarozumiałości wobec swojej propozycji ukutej w rozumie. To nic innego jak wejście w dialog z tym, „co jest”, „,co istnieje”. Można to przyrównać do nawyku dziecięcego, który to powoduje, że „mały człowiek” pragnie wszystkiego dotknać, pyta o wszystko, co go otacza. Czy znajdzie się w tej rzeczywistości obecność Boga? Zapewne wtedy jest łatwiej, gdy jest się jeszcze ciagle głodnym i niezaspokojonym tym, co istnieje. L. Giussani napisze: „Ta ciekawość nie jest niczym innym, jak pierwszą sympatia wobec bytu rzeczywistości, jakby podstawową hipotezą pracy, z jaką natura skłania człowieka do powszechnego porównania. Ta sympatia wobec rzeczywistości jest fundamentalną hipotezą pracy jako przesłanka każdego działania, każdej aktywności" ${ }^{50}$. Akwinacie nie chodzi o nic innego, jak właśnie o pozytywną zdolność (aptitudo naturalis) przyjęcia tego, co daje nam res sama w sobie. To jest „łaska” dialogu ze stworzeniem. Chciałoby się powiedzieć, że jest to warunek „,kontemplacji przyrodzonej”, a nasze spojrzenie koncentruje się na tym, co kochamy na zewnątrz. To esse jest nieuwarunkowaną pełnią i doskonałością wszelkiej rzeczywistości, Bóg nie może być określony jako byt świata stanowiąc jego przyczynę sprawczą wzorczą i celową. Słusznie zatem M. Szulakiewicz (wspomina się o tym na początku artykułu) protestuje przeciwko przesłonięciu Boga przez esse. Bóg jest całkowicie Inny, „bliski” i „daleki” jednocześnie. Wiedza o Bogu, dostępna dla człowieka, to wiedza o tym, czym On nie jest. Tomaszowa pedagogika pozwala nam poznać także Jego oddalenie. Niemniej jednak Jakub w Rdz 32, 31 wyzna „Widziałem Boga twarzą w twarz". Także H. Newman w swojej Apologia pro vita sua wspomina o tym, że idąc ulicą pewnego dnia został przeszyty intuicją, że istnieją tylko „dwa byty oczywiste same w sobie: ja i Bóg”51. Otwiera to kolejne pytania. Tomasz wychowuje nas do postawy pytającej. Człowiek zaś kocha świat. Czy kocha jego Stwórcę?

\footnotetext{
49 Por. L. Giussani, Zmyst religijny, Pallottinum, Poznań 2000, s. 197-206.

${ }^{50}$ Tamże, s. 199-200.

${ }^{51}$ H. Newman, Apologia pro vita sua, przeł. S. Gąsiorowski, Wyd. Mariackie, Kraków 1948, s. 31 (por. L. Giussani, dz. cyt., s. 202).
} 
Prawdziwa trudność rodzi się od strony pedagogicznej w momencie przejścia od bytu do osoby. Jak zrozumieć na podstawie tego, co jest, nawet po dotarciu do istoty bytu, że odniesienie kieruje nas do Boga osobowego? Zapytanie odnosi się do realności Boga, który jest zdolny do relacji, do miłości? Chodzi tutaj zatem o ową zasadę relacyjną „Ja”-,,Ty” Martina Bubera. Tomasz rozwiązuje tę trudność, rozpoczynając od strony ,antropologii integralnej”, z drugiej zaś od wskazania na swoją filozofię osoby. Do antropologii Tomasza należy jedność natury ludzkiej, także jedność rozumu, woli i uczuciowości, poznania i chcenia. Jedność władz duszy, dająca wewnętrzny pokój w sobie, oczyszcza człowieka. Jest to kondycja oglądu rzeczy szerzej niż tylko rozumem, ale całym sobą. Jest to jednak dopiero wstęp rozwiązania. Bez watpienia Tomasz z Akwinu jest zwolennikiem teizmu personalistycznego. Słowo „Bóg” rezerwuje się dla takiej istoty, która jest samoświadoma i wolna, a więc jest osobą. Definicja sformułowana przez Boecjusza, że „osoba jest indywidualną substancją rozumnej natury” (persona est rationalis naturae individua substantia), wyznaczyłą zbiór cech osoby: substancjalność, indywidualność, rozumność, także wolność i niekomunikowalność (incommunicabilitas). Czy istnieje taka osoba jak Bóg? Problem należy do tych zasadniczych. Tomasz mógłby powiedzieć, że do takiej istoty jak Bóg, do takiego rodzaju bytu, z definicji wchodzi wszystko, a to oznacza także kwestię bycia osobą. Do tego dochodzi także cała pełnia tego, kto jest osobą. Rozszerzenie to obejmuje także wieczność, i to co najtrudniejsze do przyjęcia: cielesność i cierpienie. Realność wcielenia i cierpienia dotyczy, wbrew Arystotelesowi, wewnętrznego życia Boga: musi się On ,zaprzeć” bycia wszechmocą i pełnią szczęśliwości pojętej na miarę rozkoszy. To wewnętrzny realizm Wcielenia, który Tomasz rozpatruje w swojej Sumie teologicznej, w traktacie o Trójcy Świętej ${ }^{52}$ i o wcieleniu ${ }^{53}$. Człowiek zatem wpatrzony $\mathrm{w}$ to, co jest esse, sam też jako osoba należy do świata, odkrywa jakby plan Boga. Chociaż Wcielenie było ,zdarzeniem akosmicznym" ${ }^{54}$, to ma ono w sobie ,wyglądanie Boga”, a realnie descensio (schodzenie) Boga ku człowiekowi. Bezsprzecznie cała realność świata jest już pierwszą zapowiedzią tego wydarzenia, a istnienie człowieka jako osoby wybitnym ,wprowadzeniem” tego tematu do filozoficznych rozważań. Pedagogika chrześcijańska nie ma zatem nigdy strachu przed potwierdzeniem bytu, wszelkie badania i nauka nie ogarniają jej strachem. Człowiek może

${ }^{52}$ Por. S. Th., I, qq. 39-43, zwłaszcza zagadnienie 43 (Posłanie Osób boskich).

${ }^{53}$ Por. S. Th., III, qq. 1-15.

${ }^{54}$ Por. St. Judycki, Personalistyczny teizm i pojęcie osoby, w: J. Pyda (red.), Teologia filozoficzna. Wokót ksiażki Stanisława Judyckiego „Bóg i inne osoby”, „W drodze”, Poznań-Kraków 2013, s. 293. 
wierzyć zewnętrzności i swoim zmysłom, a także sile napędowej rozumu, która dąży do wejścia w nieznane.

\section{Closeness and Infinity. A Few Comments on the Presence of God in the World Based on "Negative Philosophy" of Thomas Aquinas Read Today (Summary)}

Thomas Aquinas is said to be a representative of extreme scholastic intellectualism. Analyses conducted in the article on the basis of question 8 from Summa Theologiae, De existentia Dei in rebus (On the presence of God in things) show however that his greatness is of entirely different stature. The opposition of closeness and distance with God, existence or relation, do not create a separate alternative: either - or, but rather characteristics of complementarity for those perspectives. Aquinas illustrates certain tension between religion of the mind and religion of the relation (personal). It can be notably seen in his analysis of presence of God in things in things, but one certainly cannot claim he forgets lively closeness with God. Understanding is a field of human mind, nevertheless it is simultaneously realised by participation of love relation. Presence-God's being in the world is the juxtaposition of the Infinite with the finite, the juxtaposition full of respect and cooperation, as soon as in the first stage of mutual understanding of the truth about the situation of the beginning, where God is the Creator, the world, things, the man possesses within the gift of the received existence. The situation begins to crystallize more and more, when a man as a rational being is invited to take a "position", that is in the entire freedom of self-realisation, in space and time provided by God. How can you not wonder about this invitation for personal relation of friendship and love. All three lines of thought, presented by Aquinas, God's presence in things per essentiam, potentiam and paesentiam as necessity are illustrated as if they were separate sections of subsequent attempts and actions. It is however the one, exceptional presence of God in the world.

It has its own educational implications: it opens up the great perspective of upbringing towards "the freedom of attention" and upbringing towards "the freedom of question". Thomas Aquinas refers with great force to the reality of the world, to the insight into the thing which exists as created, without concern that a man would have too many questions. Actually, there might be too few questions. Contemporary thinking concentrates so much on thinking patterns of a man that it does not seem to notice the reality of the world, and the "language of God" in this reality. The upbringing "of attention" is nothing else but accepting the proposition given by the reality of things openly, without conceit towards own proposition coined in the mind. The question about res is also accompanied by the question about the person. The 
word "God" is reserved for such a being, who is self-aware and free, therefore it is a person. A man having his eyes fixed on what is esse, has his eyes fixed on himself, as a person he also belongs to the world, and here he discovers God's plan, "longing for" Incarnation. Here the question of personalistic theism is resolved. Christian education is never afraid of confirming existence, all researches and science do not cover it with fear. A man can believe the appearance and his senses, as well as the driving force of the mind, which strives to enter the unknown.

Keywords: negative philosophy; God; presence; relationship; Thomas Aquinas.

\section{Bliskość i nieskończoność. Kilka uwag na temat obecności Boga w świecie na kanwie „filozofii negatywnej” św. Tomasza z Akwinu odczytanej dzisiaj (Streszczenie)}

O św. Tomaszu mówi się, że jest przedstawicielem skrajnego scholastycznego intelektualizmu. Analizy tutaj uczynione wskazują jednak, że jego wielkość jest zupełnie odmiennego formatu. Opozycja bliskość, oddalenie Boga, byt czy relacja, nie są u niego alternatywą rozłączną: albo-albo, lecz raczej wyróżnikiem komplementarności tych spojrzeń. Zapewne Akwinata odzwierciedla pewne napięcie pomiędzy religią rozumu i religią relacji (osobowej). Widać to w jego analizie bycia Boga w rzeczach bardzo dobitnie, ale nie można twierdzić, że o żywej bliskości z Bogiem zapomina. Zrozumienie jest sferą ludzkiego umysłu, ale dokonuje się równocześnie przy współudziale relacji miłości. Obecność-bycie Boga w świecie to spotkanie Nieskończonego ze skończonością, spotkanie pełne szacunku i podjętej współpracy, nawet już w pierwszej fazie wzajemnego zrozumienia prawdy o sytuacji początku, gdzie Bóg jest Stwórca, świat, rzeczy, człowiek posiada w darze otrzymanego istnienia. Potem sytuacja zaczyna się coraz bardziej krystalizować, gdy człowiek jako stworzenie rozumne zostaje zaproszony do zajmowania „miejsca”, czyli w pełnej wolności urzeczywistnienia siebie, w przestrzeni i czasie darowanym przez Boga. A jakże nie zadziwić się nad owym zaproszeniem do osobowej relacji przyjaźni i miłości. Wszystkie te trzy tory rozumowania, które przedstawia Akwinata, bycie Boga w rzeczach per essentiam, potentiam i paesentiam z konieczności prezentowane są jakby były osobnymi sekcjami kolejnych podejść i działań. Jest to jednak jedno, wyjątkowe bycie Boga w świecie.

Z punktu widzenia pedagogiki jest to ważne, gdyż otwiera wielką pespektywę wychowania do „wolności do uwagi” i wychowania do „wolności pytającej”. Tomasz z Akwinu odsyła bowiem z wielką mocą do rzeczywistości świata, do wglądu w to, co istnieje jako stworzone, bez obawy, że człowiek będzie miał za wiele pytań. Pytań może być właśnie za mało. Tak bardzo myśl współczesna koncentruje się 
na konstrukcjach myślowych człowieka, że nie zauważa realności świata i „mowy Boga” w tejże realności. Wychowanie „do uwagi” to nic innego, jak przyjęcie propozycji dawanej przez rzeczywistość rzeczy, i to w sposób otwarty, bez zarozumiałości wobec swojej propozycji ukutej w rozumie. Pytaniu o rzecz towarzyszy pytanie o osobę. Słowo „Bóg” rezerwuje się dla takiej istoty, która jest samoświadoma i wolna, a więc jest osobą. Człowiek zatem wpatrzony w to, co jest esse, sam też jako osoba należy do świata, odkrywa jakby plan Boga, ,pragnienie” Wcielenia. W ten sposób zostaje rozwiązany problem teizmu personalistycznego. Pedagogika chrześcijańska nie ma zatem nigdy strachu przed potwierdzeniem bytu, wszelkie badania i nauka nie ogarniają jej strachem. Człowiek może wierzyć zewnętrzności i swoim zmysłom, a także sile napędowej rozumu, która dąży do wejścia w nieznane.

Słowa kluczowe: filozofia negatywna; Bóg; obecność; relacja; Tomasz z Akwinu. 